\title{
Laboratory Device Detecting the Magnitude of the Static Friction Coefficient of Brake Lining
}

\author{
Leopold Hrabovský1*, Roman Hrbáč ${ }^{2}$ \\ 1 VSB Technical University of Ostrava, Faculty of Mechanical Engineering, Institute of Transport, 17. listopadu \\ 2172/15, 70800 Ostrava-Poruba, Czech Republic \\ 2 VSB Technical University of Ostrava, Faculty of Electrical Engineering and Computer Science, Department of \\ Electrical Engineering, 17. listopadu 2172/15, 70800 Ostrava-Poruba, Czech Republic \\ * Corresponding author's email: leopold.hrabovsky@vsb.cz
}

\begin{abstract}
The paper describes the design of laboratory equipment, which was created for verification and determination of the value of the static coefficient of friction in the contact surfaces of the brake lining and the brake drum of the drum brake with external shoes by experimental procedure. Suppliers of brake linings state the values of the friction coefficients which correspond to different operating temperatures, but do not state the values of the friction coefficient of the respective brake lining with regard to the state of contamination of the contact surfaces. In practice, the brake contact surfaces are exposed to moisture, dust, lubricants and oils; these weather and operational influences significantly affect the value of the coefficient of friction. The results of the laboratory tests performed with two types of brake linings (commonly used in practice) (fabric, hardened rubber) show that the coefficient of friction of a given brake lining is strongly influenced by the state of contamination of the contact surfaces.
\end{abstract}

Keywords: friction coefficient, brake lining, dual-caliper drum brake.

\section{INTRODUCTION}

Braking and maintaining at rest the rotational movement of the drive unit of the lifting [7], travel [3, 21], rotating and tilting mechanism of a crane, the torque of a drum or friction elevator machine [6], or the torque of the drives of continuously operating conveyor equipment [ 9 , 11] involve the use of the drum, solid disc [19], vented disc or belt brakes [17].

When braking using drum brakes with external shoes (clasp brakes) [18], the brake shoes are pressed against the outer surface of the drum, creating friction that changes kinetic energy to heat energy and creates braking force. The magnitude of the braking force $F_{b}[\mathrm{~N}]$ is determined as the sum of the frictional forces that arise on the contact surfaces of the shoes and the brake drum housing. The friction force of the brake shoe depends on the magnitude of the pressure (normal) force and on the coefficient of shear friction of the brake lining used. Shear friction is a physical phenomenon that occurs when one body (brake lining) slides over the surface of another body (brake drum housing). Its origin is mainly in the unevenness of the two contact surfaces with which the bodies touch each other. The frictional force preventing the body from moving is greater than the frictional force that decelerates the moving body. Therefore, we distinguish between static and dynamic friction. The static shear coefficient $f_{S}[-]$ is greater than the dynamic shear coefficient $f_{d}[-]$.

The brake shoes (pads) of the drum (disk) brakes of the drive machine [10] are pressed against the brake drum (disk) at rest, even in the event of a power failure, and are released by the brake release. The release of crane brakes is usually an electro-hydraulic brake release and for elevator brakes it is an electromagnetic brake release. 
a)

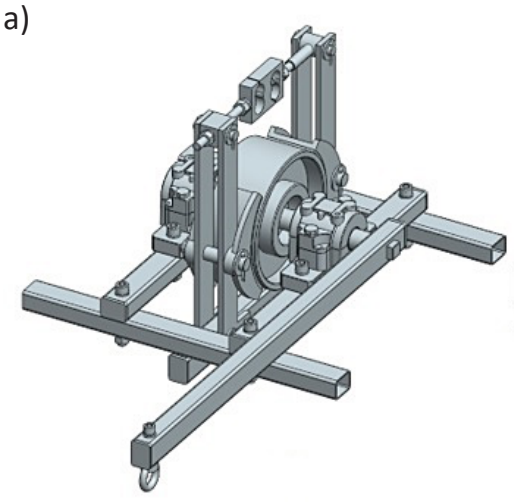

b)

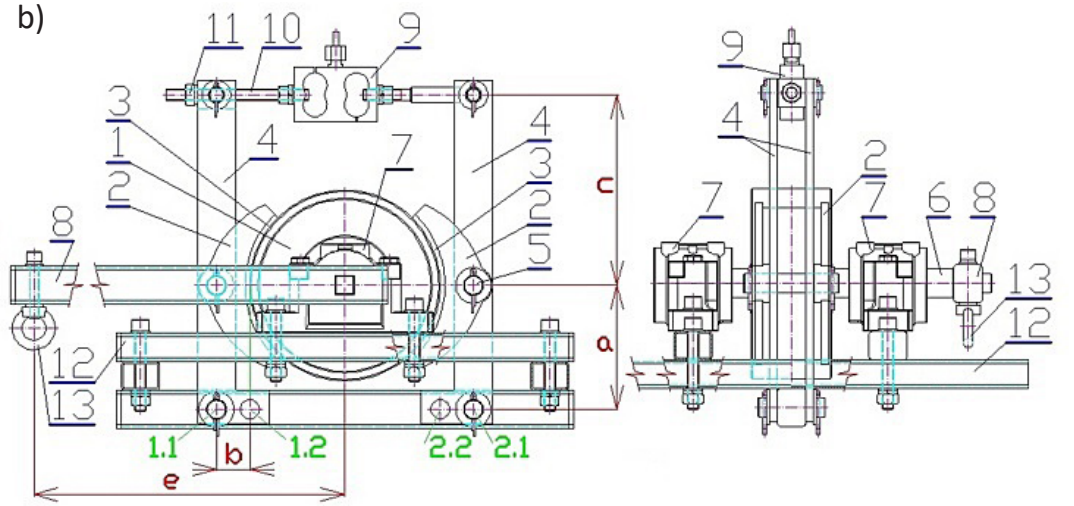

Fig. 1. The device detects the magnitude of the friction coefficient a) 3D model, b) construction design

The friction surfaces of the brakes for industrial machinery (e.g., lifting equipment) are provided with brake linings [20]. Brake linings [2] are manufactured in the form of belts [13] or plates [14], in pressed [15] or knitted [16] versions. The brake linings are glued (hot or cold) to the brake shoes or pads or riveted.

\section{CONSTRUCTION COMPONENTS, PARTS AND DESCRIPTION OF LABORATORY DEVICE}

The laboratory research and testing, involved a welded steel structure on which industrial double-shoe brakes are placed, see Figure 3, which are commonly used in lifting equipment for elevators [6] and cranes [7].

Figure 1 presents a 3D design model created in the SolidWorks 2012x64 Edition SP05 $3 \mathrm{D}$ CAD system and a drawing created in AutoCAD 2010, a laboratory device designed to perform experimental tests to determine the magnitude of the static coefficient of friction of the brake linings.

The hub (see Figure 1b) with a brake drum diameter of $30 \mathrm{~mm} 1$ (diameter of $200 \mathrm{~mm}$ and width $85 \mathrm{~mm}$ ) is attached to the shaft 6 by a tight spring $(8 \times 7 \times 56)$. The vertical displacement of the brake drum 1 relative to the shaft 6 is ensured by retaining shaft rings. Two double-row tilting ball bearings (type $1207 \mathrm{~K}$ ) are pressed onto the shaft 6 , which are mechanically connected to the welded steel structure 12 by two bearing bodies [21] (type SNL 507-606).

Both brake shoes 2 are attached to the lever arms 4 by pins 5 (diameter $20 \mathrm{~mm}$, length 100 $\mathrm{mm}$ ). The examined brake lining 3 is riveted to the brake shoes 2 . Two holes (with a spacing of $35 \mathrm{~mm}$ ) with a diameter of $20 \mathrm{~mm}$ are drilled into the lower part of both levers 4 . The pins (diameter $20 \mathrm{~mm}$, length $70 \mathrm{~mm}$ ) are attached to the lower parts of the levers 4 to the closed profiles 40x30×2 mm, which are part of the steel structure 12 of the described laboratory equipment.

A hole with a diameter of $15 \mathrm{~mm}$ is drilled in the upper part of both levers 4. M12 threaded rods are attached to these holes using the designed construction components. One end part of both threaded rods is screwed onto the internal threads M12 of the strain gauge load cell 9 (type RSC-1 $\mathrm{T}[22]$ ). By tightening the nut 11 , a tensile force is exerted in the threaded rod 10 , the magnitude of which is detected by the load cell 9 .

In one of the end portions of the shaft 6 , a square $40 \mathrm{~mm}$ long with a side of $20 \mathrm{~mm}$ is formed. The square hole in the tension rod 8 is pushed onto the square of the shaft 6 during laboratory measurements. A suspension nut M8 13 is fastened to the tension rod 8 (length $702 \mathrm{~mm}$ ) with a screw.

\section{NUMERICAL RELATIONSHIPS DEFINING THE VALUE OF THE FRICTION COEFFICIENT}

The magnitude of the static coefficient of friction $f_{S}$ of the brake lining can be expressed according to relation (9), which was derived from the equations of the torques of forces (1) and (2) compiled to points 1.1 and 2.1, see Figure 2a.

$$
\begin{aligned}
& \sum \mathrm{M}_{1.1}=0: \mathrm{F}_{1} \cdot \mathrm{a}+\mathrm{F}_{1} \cdot \mathrm{f}_{\mathrm{s}} \cdot \mathrm{b}=\mathrm{F} \cdot(\mathrm{a}+\mathrm{c}) \\
& \sum \mathrm{M}_{2.1}=0: \mathrm{F}_{2} \cdot \mathrm{a}=\mathrm{F}_{2} \cdot \mathrm{f}_{\mathrm{s}} \cdot \mathrm{b}+\mathrm{F} \cdot(\mathrm{a}+\mathrm{c})
\end{aligned}
$$



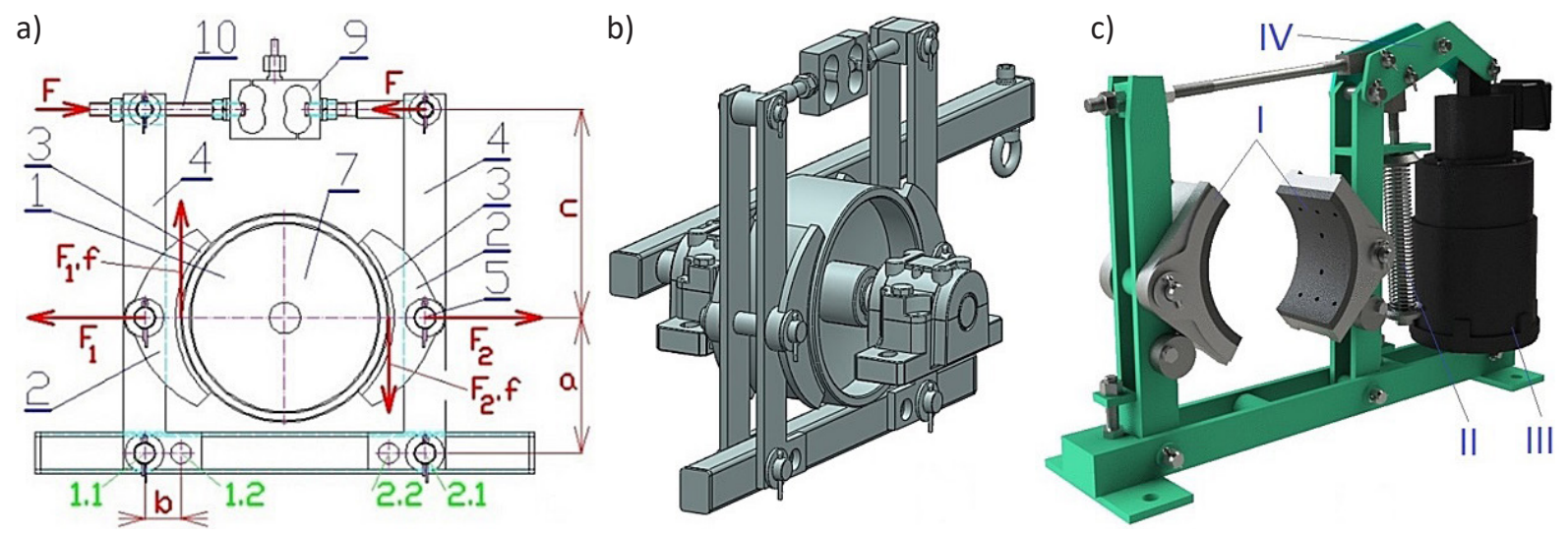

Fig. 2. Dual-caliper drum brake a) acting forces, b) 3D model, c) with outer shoes

By mathematically modifying equations (1) and (2), the magnitude of the pressing forces $F_{i}$ (3), (4) of the brake shoes 2 against the brake drum 1 and the magnitude of the tensile force $F$ $[N]$, acting in the threaded rod 10 and detected by the load cell can be determined 9 .

$$
\begin{aligned}
& F_{1}=\frac{F \cdot(a+c)}{a+f_{s} \cdot b} \Rightarrow F=\frac{F_{1} \cdot\left(a+f_{s} \cdot b\right)}{a+c} \\
& F_{2}=\frac{F \cdot(a+c)}{a-f_{s} \cdot b} \Rightarrow F=\frac{F_{2} \cdot\left(a-f_{s} \cdot b\right)}{a+c}
\end{aligned}
$$

According to equation (3) and (4), it follows that the pressing forces $F_{i}$ are not of the same magnitude. They reach the same magnitudes of force $F_{i}$ when the expression $f_{S} \cdot b$ acquires zero values in the denominator $(F, a$, $c$ cannot be zero). In practice, the two pressing forces $F_{i}$ of the same magnitude can be achieved by moving the pivot pins of the lower parts of the lever arms 1 from point 1.1 to 1.2 and from point 2.1 to 2.2 , see Figure 2a, (vertical components of frictional forces $F_{1} \cdot f_{S}$ and $F_{2} \cdot f_{S}$ then through points 1.2 and 2.2 , and the arms have moment of force, $F_{1} \cdot f_{S} \cdot b$ and $F_{2}$. $f_{S} \cdot b$, of $b=0$ ).

In laboratory measurements, the torque $M_{k}$ $[\mathrm{N} \cdot \mathrm{m}](5)$ on the circumference of the brake drum 1 is exerted by the pull of the weight $G_{Z}[\mathrm{~N}]$, which is suspended at a distance of $e=642 \mathrm{~mm}$ (see Figure 1b, measured from the vertical axis of the square opening with $20 \mathrm{~mm}$ sides) on a suspension nut 13 of the rod 8 (rod weight $\left.8 G_{p}=13.7 \mathrm{~N}\right)$. The center of gravity of the rod 8 is found at the distance $d=332 \mathrm{~mm}$.

$$
\mathrm{M}_{\mathrm{k}}=\mathrm{G}_{\mathrm{p}} \cdot \mathrm{d}+\mathrm{G}_{\mathrm{z}} \cdot \mathrm{e}
$$

In order to reduce the torque $M_{k}(5)$, i.e., in order for the driving force $F_{k}[\mathrm{~N}](6)$ on the circumference of the brake drum 1 to be zero, it is necessary for the double-caliper brake to exert the braking force $F_{b}[\mathrm{~N}](7)$.

$$
\begin{aligned}
M_{k}=F_{k} \cdot R & \Rightarrow F_{k}=\frac{M_{k}}{R}=\frac{G_{p} \cdot d+G_{z} \cdot e}{R}(6) \\
F_{b} & =\left(F_{1}+F_{2}\right) \cdot f_{s} \geq F_{k}
\end{aligned}
$$

Substituting the expressions from equations (3) and (4) into equation (7) under the compressive forces $F_{1}$ and $F_{2}$, we obtain the quadratic equation (8), whose two roots $f_{s 1, s 2}[-]$ are given in equation (9).

$$
\begin{gathered}
\mathrm{F}_{\mathrm{k}} \cdot \mathrm{b}^{2} \cdot \mathrm{f}_{\mathrm{s}}^{2}+\mathrm{F} \cdot(\mathrm{a}+\mathrm{c}) \cdot 2 \cdot \mathrm{a} \cdot \mathrm{f}_{\mathrm{s}}-\mathrm{F}_{\mathrm{k}} \cdot \mathrm{a}^{2}=0 \\
\mathrm{f}_{\mathrm{s} 1, \mathrm{~s} 2}=\frac{-\mathrm{F} \cdot(\mathrm{a}+\mathrm{c}) \cdot 2 \cdot \mathrm{a} \pm \sqrt{\mathrm{D}}}{2 \cdot \mathrm{F}_{\mathrm{k}} \cdot \mathrm{b}^{2}}
\end{gathered}
$$

where $D=F^{2} \cdot(a+c)^{2} \cdot 4 \cdot a^{2}+4 \cdot F_{k}^{2} \cdot b^{2} \cdot a^{2}$.

Under operating conditions, when the drive motor of the hoisting device is at rest (i.e., when not in use), the calipers I (see Figure 2c) of the disc brake [17] are pressed against the circumference of the brake drum by the force of the preloaded coil spring II [5] (or weight).

If current is applied to the drive motor of the lifting mechanism when lifting or lowering the load, current is supplied to the motor of the electrohydraulic brake release III at the same time. In the electrohydraulic brake release III, the oil is pumped through the impeller of the pump from the space above the piston to the space below the piston, which rises with the oil overpressure. The piston rod of the electrohydraulic brake release III moves the shoes I away from the brake disc via the rods IV. 


\section{EXPERIMENTAL DETERMINATION OF STATIC FRICTION COEFFICIENT OF BRAKE LINING}

The working surfaces of drum brake shoes with external shoes, see Figure 2c, are fitted with a brake lining made of knitted fiber $[15,16]$ or hardened rubber $[12,14]$. The brake lining is required to have a high coefficient of friction, high wear resistance, withstand high temperatures and not to squeal during braking.

MBL 5820 [13] and WBL 9850 [15] brake linings were used for the experimental tests performed in the laboratory research and testing,
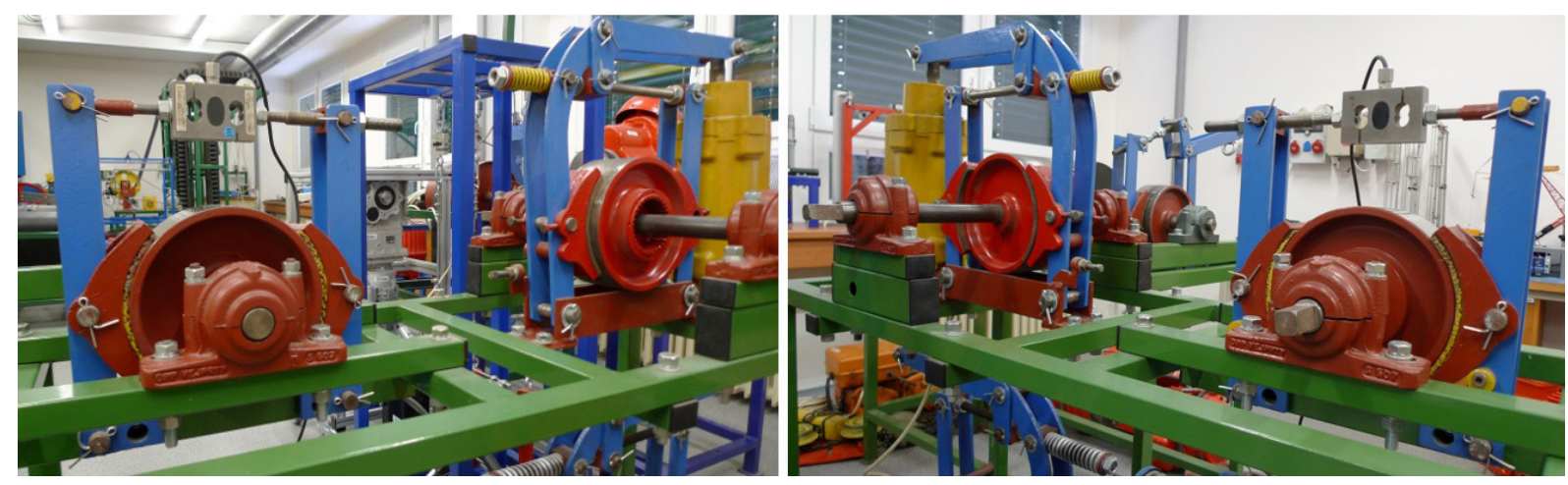

Fig. 3. Laboratory device detecting the magnitude of the static friction coefficient of brake lining

Table 1. Brake lining WBL 9850, dry conditions of contact surfaces

\begin{tabular}{|c|c|c|c|c|c|c|c|c|c|c|c|}
\hline $\mathbf{i}$ & 1 & 2 & 3 & 4 & 5 & $\mathbf{i}$ & 1 & 2 & 3 & 4 & 5 \\
\hline$G_{z}[\mathrm{~N}]$ & \multicolumn{5}{|c|}{$m_{z} \cdot g=7.08 \cdot 9.81=96.5$} & $G_{z}[\mathrm{~N}]$ & \multicolumn{5}{|c|}{$m_{z} \cdot g=10.75 \cdot 9.81=105.5$} \\
\hline$F_{k}[\mathrm{~N}]$ & \multicolumn{5}{|c|}{491.3} & $F_{k}[\mathrm{~N}]$ & \multicolumn{5}{|c|}{722.4} \\
\hline$M_{k}[\mathrm{~N} \cdot \mathrm{m}]$ & \multicolumn{5}{|c|}{$F_{k} \cdot R=491.3 \cdot 0.1=49.1$} & $M_{k}[\mathrm{~N} \cdot \mathrm{m}]$ & \multicolumn{5}{|c|}{$F_{k} \cdot R=722.4 \cdot 0.1=72.2$} \\
\hline$F_{i}[\mathrm{~N}]$ & 192.1 & $199.4^{* 1}$ & 191.3 & 189.7 & 195.2 & $F_{i}[\mathrm{~N}]$ & 296.0 & 282.4 & 295.4 & 288.7 & 285.6 \\
\hline$f_{s(i)}[-]$ & 0.58 & 0.56 & 0.58 & 0.59 & 0.57 & $f_{s(i)}[-]$ & 0.55 & 0.58 & 0.56 & 0.57 & 0.57 \\
\hline \multicolumn{2}{|c|}{$\Sigma f_{s(i)}=2.88$} & \multicolumn{2}{|c|}{$\Sigma f_{s(i)} / n=0.58$} & \multicolumn{2}{|c|}{$k_{5 \%, 5}= \pm 0.01$} & \multicolumn{2}{|c|}{$\Sigma f_{s(i)}=2.83$} & \multicolumn{2}{|c|}{$\Sigma f_{s(i)} / n=0.57$} & \multicolumn{2}{|c|}{$k_{5 \%, 5}= \pm 0.01$} \\
\hline
\end{tabular}

${ }^{1}$ see Figure $4 \mathrm{a}$

Table 2. Brake lining WBL 9850, dry conditions of contact surfaces

\begin{tabular}{|c|c|c|c|c|c|c|c|c|c|c|c|}
\hline $\mathbf{i}$ & 1 & 2 & 3 & 4 & 5 & $\mathbf{i}$ & 1 & 2 & 3 & 4 & 5 \\
\hline$G_{z}[\mathrm{~N}]$ & \multicolumn{5}{|c|}{$m_{z} \cdot g=15.68 \cdot 9.81=153.8$} & $G_{z}[\mathrm{~N}]$ & \multicolumn{5}{|c|}{$m_{z} \cdot g=20.74 \cdot 9.81=203.6$} \\
\hline$F_{k}[\mathrm{~N}]$ & \multicolumn{5}{|c|}{1032.8} & $F_{k}[\mathrm{~N}]$ & \multicolumn{5}{|c|}{1351.3} \\
\hline$M_{k}[\mathrm{~N} \cdot \mathrm{m}]$ & \multicolumn{5}{|c|}{$F_{k} \cdot R=1032.8 \cdot 0.1=103.3$} & $M_{k}[\mathrm{~N} \cdot \mathrm{m}]$ & \multicolumn{5}{|c|}{$F_{k} \cdot R=1351.3 \cdot 0.1=135.1$} \\
\hline$F_{i}[\mathrm{~N}]$ & 423.2 & 431.0 & 434.1 & $404.3^{* 2}$ & 418.7 & $F_{i}[\mathrm{~N}]$ & 574.2 & 543.1 & 559.8 & 561.0 & 548.4 \\
\hline$f_{s(i)}[-]$ & 0.55 & 0.54 & 0.54 & 0.58 & 0.56 & $f_{s(i)}[-]$ & 0.53 & 0.57 & 0.55 & 0.55 & 0.56 \\
\hline \multicolumn{2}{|c|}{$\Sigma f_{S(i)}=2.79$} & \multicolumn{2}{|c|}{$\Sigma f_{s(i)} / n=0.56$} & \multicolumn{2}{|c|}{$k_{5 \%, 5}= \pm 0.03$} & \multicolumn{2}{|c|}{$\Sigma f_{S(i)}=2.76$} & \multicolumn{2}{|c|}{$\Sigma f_{s(i)} / n=0.55$} & \multicolumn{2}{|c|}{$k_{5 \%, 5}= \pm 0.02$} \\
\hline
\end{tabular}

${ }^{* 2}$ see Figure $4 b$

Table 3. Brake lining WBL 5820, dry conditions of contact surfaces

\begin{tabular}{|c|c|c|c|c|c|c|c|c|c|c|c|}
\hline $\mathbf{i}$ & 1 & 2 & 3 & 4 & 5 & $\mathbf{i}$ & 1 & 2 & 3 & 4 & 5 \\
\hline$G_{Z}[\mathrm{~N}]$ & \multicolumn{5}{|c|}{96.5} & $G_{z}[\mathrm{~N}]$ & \multicolumn{5}{|c|}{105.5} \\
\hline$F_{i}[\mathrm{~N}]$ & 231.5 & 216.8 & 225.4 & 221.2 & 209.7 & $F_{i}[\mathrm{~N}]$ & 352.9 & 342.4 & 372.8 & 348.1 & 351.7 \\
\hline$f_{s(i)}[-]$ & 0.48 & 0.52 & 0.50 & 0.50 & 0.53 & $f_{s(i)}[-]$ & 0.47 & 0.48 & 0.44 & 0.47 & 0.47 \\
\hline \multicolumn{2}{|c|}{$\Sigma f_{s(i)}=2.53$} & \multicolumn{2}{|c|}{$\Sigma f_{S(i)} / n=0.51$} & \multicolumn{2}{|c|}{$k_{5 \%, 5}= \pm 0.02$} & \multicolumn{2}{|c|}{$\Sigma f_{s(i)}=2.33$} & \multicolumn{2}{|c|}{$\Sigma f_{s(i)} / n=0.47$} & \multicolumn{2}{|c|}{$k_{5 \%, 5}= \pm 0.02$} \\
\hline
\end{tabular}


Table 4. Brake lining WBL 5820, dry conditions of contact surfaces

\begin{tabular}{|c|c|c|c|c|c|c|c|c|c|c|c|}
\hline $\mathbf{i}$ & 1 & 2 & 3 & 4 & 5 & $\mathbf{i}$ & 1 & 2 & 3 & 4 & 5 \\
\hline$G_{z}[\mathrm{~N}]$ & \multicolumn{5}{|c|}{153.8} & $G_{z}[\mathrm{~N}]$ & \multicolumn{5}{|c|}{203.6} \\
\hline$F_{i}[\mathrm{~N}]$ & 504.0 & 499.4 & 489.3 & 503.8 & 492.4 & $F_{i}[\mathrm{~N}]$ & 639.5 & 653.9 & 659.3 & 641.2 & 649.1 \\
\hline$f_{s(i)}[-]$ & 0.47 & 0.47 & 0.48 & 0.47 & 0.48 & $f_{s(i)}[-]$ & 0.48 & 0.47 & 0.47 & 0.48 & 0.47 \\
\hline \multicolumn{2}{|c|}{$\Sigma f_{S(i)}=2.37$} & \multicolumn{2}{|c|}{$\Sigma f_{s(i)} / n=0.47$} & \multicolumn{2}{|c|}{$k_{5 \%, 5}= \pm 0.01$} & \multicolumn{2}{|c|}{$\Sigma f_{S(i)}=2.37$} & \multicolumn{2}{|c|}{$\Sigma f_{S(i)} / n=0.47$} & \multicolumn{2}{|c|}{$k_{5 \%, 5}= \pm 0.01$} \\
\hline
\end{tabular}

Table 5. Brake lining WBL 5820, oil contaminated state of contact surfaces

\begin{tabular}{|c|c|c|c|c|c|c|c|c|c|c|c|}
\hline $\mathbf{i}$ & 1 & 2 & 3 & 4 & 5 & $\mathbf{i}$ & 1 & 2 & 3 & 4 & 5 \\
\hline$G_{z}[\mathrm{~N}]$ & \multicolumn{5}{|c|}{96.5} & $G_{z}[\mathrm{~N}]$ & \multicolumn{5}{|c|}{105.5} \\
\hline$F_{i}[\mathrm{~N}]$ & 406.5 & 454.4 & 426.3 & 432.2 & 428.9 & $F_{i}[\mathrm{~N}]$ & 733.2 & 704.8 & 716.9 & 668.7 & 727.8 \\
\hline$f_{s(i)}[-]$ & 0.27 & 0.25 & 0.26 & 0.26 & 0.26 & $f_{s(i)}[-]$ & 0.22 & 0.23 & 0.23 & 0.25 & 0.23 \\
\hline \multicolumn{2}{|c|}{$\Sigma f_{S(i)}=1.30$} & \multicolumn{2}{|c|}{$\Sigma f_{s(i)} / n=0.26$} & \multicolumn{2}{|c|}{$\mathrm{k}_{5 \%, 5}= \pm 0.01$} & \multicolumn{2}{|c|}{$\Sigma f_{s(i)}=1.16$} & \multicolumn{2}{|c|}{$\Sigma f_{s(i)} / n=0.23$} & \multicolumn{2}{|c|}{$k_{5 \%, 5}= \pm 0.01$} \\
\hline
\end{tabular}

Table 6. Brake lining WBL 5820, oil contaminated state of contact surfaces

\begin{tabular}{|c|c|c|c|c|c|c|c|c|c|c|c|c|}
\hline $\mathbf{i}$ & $\mathbf{1}$ & $\mathbf{2}$ & $\mathbf{3}$ & $\mathbf{4}$ & $\mathbf{5}$ & $\mathbf{i}$ & $\mathbf{1}$ & $\mathbf{2}$ & $\mathbf{3}$ & $\mathbf{4}$ & $\mathbf{5}$ \\
\hline$G_{\mathrm{z}}[\mathrm{N}]$ & \multicolumn{9}{|c|}{153.8} \\
\hline$F_{i}[\mathrm{~N}]$ & 1084.2 & 929.4 & 1020.4 & 1104.5 & 1005.2 & $F_{i}[\mathrm{~N}]$ & 1506.0 & 1426.9 & 1421.4 & 1469.2 & 1402.9 \\
\hline$f_{s(i)}[-]$ & 0.22 & 0.25 & 0.23 & 0.21 & 0.23 & $f_{s(i)}[-]$ & 0.20 & 0.22 & 0.22 & 0.21 & 0.22 \\
\hline \multicolumn{2}{|c|}{$\Sigma f_{s(i)}=1.14$} & \multicolumn{1}{|c|}{$\Sigma f_{s(i)} / n=0.23$} & \multicolumn{1}{|c|}{$k_{5 \%, 5}= \pm 0.02$} & \multicolumn{2}{|c|}{$\Sigma f_{s(i)}=1.07$} & \multicolumn{2}{|c|}{$\Sigma f_{s(i)} / n=0.21$} & $k_{5 \%, 5}= \pm 0.01$ \\
\hline
\end{tabular}
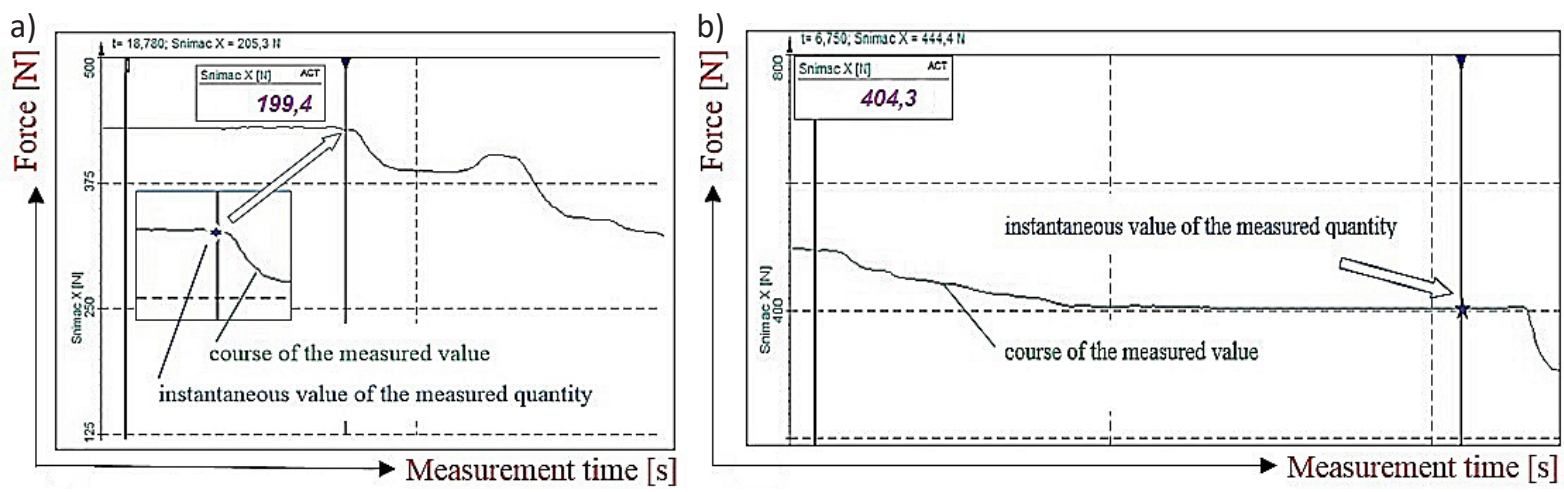

Fig. 4. Record of the course of force registered by the load cell 9 in the DEWESoft X2 SP5 software environment
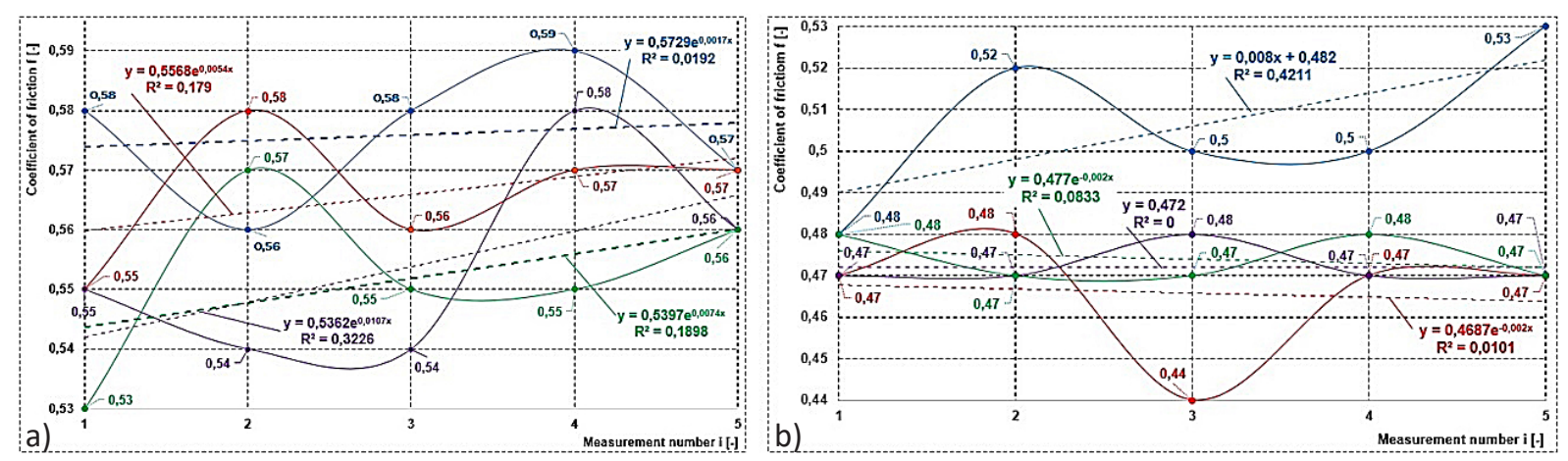

Fig. 5. Values of the friction coefficient $f$, determined by calculation according to the relationship (9) a) WBL 9850, as per Tables 1 - 2, b) WBL 9820, as per Tables 3 - 4 

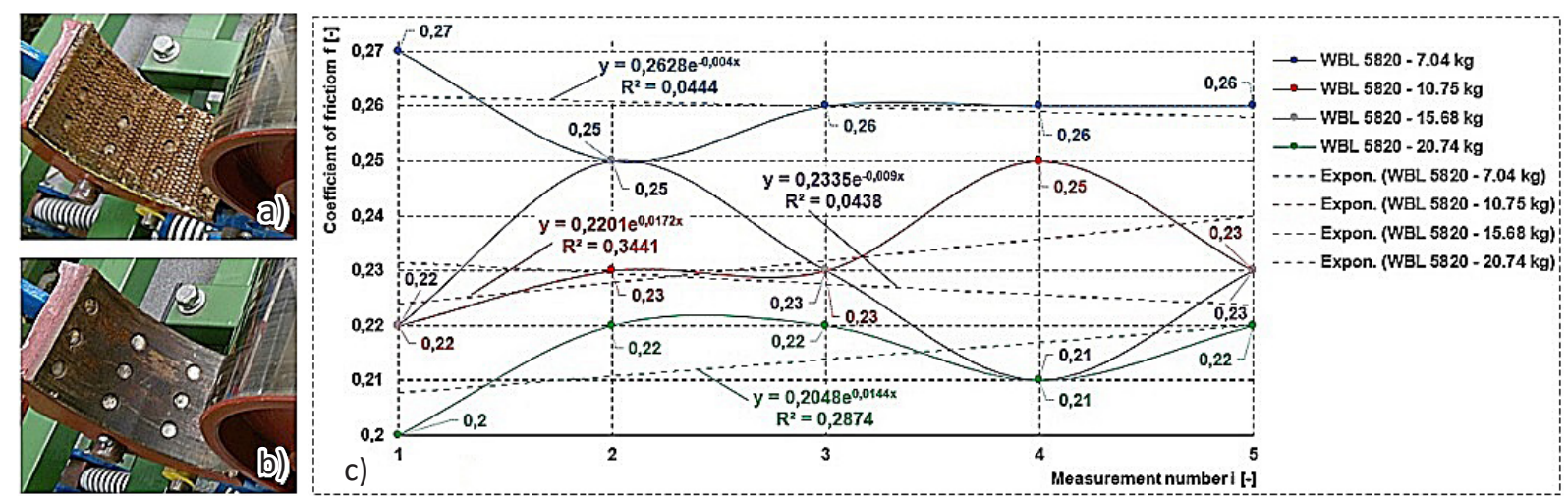

Fig. 6. Brake lining a) WBL 5850, b) WBL 5850, c) values of the friction coefficient $f_{S}$ determined by calculation according to the relationship (9), brake lining WBL 9820, according to Table 5 to Table 6

see Figure $6 \mathrm{a}, \mathrm{b}$. The laboratory measurements were performed under operating conditions to which the contact surfaces of the brake lining and the surface of the brake drum are normally exposed, under dry conditions (Table 1 to Table 4, Figure 5) and with oil contamination (Table 5 and Table 6, Figure 6c).

Figure 5 shows-represented by the dashed line the exponential trend line (for the corresponding weight of the weights $m_{z}$, see Table 1 to Table 4) as well as gives the equations of the trend lines and the coefficients of determination of $R^{2}$.

The arithmetic mean $\sum f_{S(i)} / n$ (see Table 1 to Table 6 ) of the measured values $f_{S(i)}$ was calculated with the help of relations [4]. In the table [1] of critical values of Student's distribution, the chosen risk was set to be $5 \%$, and therefore $t_{a, n}[-]$, for the number of measurements " $n=5$ " and the risk $a=$ $5 \%$ the Student's coefficient is $t_{5 \%, 5}=2.78$. The error margin $\kappa_{5} \%, 5$ was calculated by [4].

\section{CONCLUSIONS}

The construction design of the described laboratory device and its execution in the laboratory research and testing was carried out to obtain the values of the coefficient of friction of brake linings for drum brakes with external shoes, for their subsequent verification and comparison with the values declared by the manufacturer. The coefficient of friction of brake linings is often stated by the manufacturer only as a value corresponding to the operating temperature, but the coefficient of friction is not known for the contact conditions (presence of pollution, humidity, presence of lubricant and oil) under which the brakes are commonly operated.
The static value of the coefficient of friction was determined on a laboratory device using an indirect method. Gradual slow loosening of the hexagon nut in the laboratory device led to a decrease in the magnitude of the tensile force in the threaded rod, which mechanically interconnected the upper ends of the brake lever arms. The installed load cell at the point of interruption of the threaded rod detected the immediate magnitude of the applied tensile force in the threaded rod. The brake shoes were attached to both lever arms by pins, their linings were pressed against the outer circumference of the brake drum housing by pressing forces, which were derived by tightening the nut on the threaded rod. The lower ends of the lever arms were pinned to the rectangular profile of the steel frame of the laboratory device.

The electrical signal; i.e., the output voltage of the deformed measuring the strain gauges connected to the Wheatstone bridge, which is implemented in the body of the load cell; was connected to the DS-NET BR4 measuring unit (manufactured by DEWESoft $\mathrm{GmbH}$ ) via a connector. The DS-NET measuring and control unit was connected, via cable, to a PC which displayed the values of the tensile force detected by the load cell in the DEWESoft X2 SP5 software environment.

Torque was applied to the brake disc shaft from the weight of the weight suspended on the tension lever arm. In order to reduce the driving force $F_{k}$ on the circumference of the brake disc (which is directly proportional to the magnitude of the torque), it was necessary to derive a sufficient magnitude of frictional forces in the friction surfaces of the brake, which define the braking force $F_{b}$ of magnitude (7). 
The tables in Chapter 2 show the immediate values of the tensile forces $F_{i}$ detected by the load cell at the moment of the onset of the drum slip relative to the brake lining under examination. Different values of tensile forces $F_{i}$, for a given state of contact surfaces and the respective type of brake lining, were achieved by different-size weights $G_{z}$, which derived the torque $M_{k}$.

The device will be used in the study specialization Transport and Process Equipment, in bachelor's forms of study at Institute of Transport, Faculty Mechanical Engineering, VSB - Technical University of Ostrava. It will be employed to obtain values of the static coefficient of friction for different brake linings and for different states of contact surfaces, which will then be evaluated and compared.

\section{Acknowledgements}

This work has been supported by The Ministry of Education, Youth and Sports of the Czech Republic from the Specific Research Project SP2021/53.

\section{REFERENCES}

1. Mádr V., Knejzlik J., Kopečný J., Novotný I. Fyzikální měření [Physical measurements]. (In Czech), SNTL Praha 1991.

2. Durna A., Fries J., Hrabovský L., Slíva A., Žarnovsky J. Research and development of laser engraving and material cutting machine from 3D printer. Management Systems in Production Engineering. 2019,28(1):47-52.

3. Fedorko G., Molnár V., Blaho P., Gasparik J., Zitrický V. Failure analysis of cyclic damage to a railway rail. A case study. Engineering Failure Analysis. 2020,116.

4. Hrabovský L., Borovský D. Laboratory Device for Checking the Functionality of the Elevator Rope Sensors. Management Systems in Production Engineering. 2020,29(1):59-64.

5. Hrabovský L., Dluhoš D. Calibration of transducers and of a coil compression spring constant on the testing equipment simulating the process of a pallet positioning in a rack cell. Open Engineering. 2019,9(1):631-640.

6. Hrabovský L., Koščák P. Detection and Change of Tension Forces Operating on Elevator Hoist Ropes. IOP Conference Series: Materials Science and Engineering. 2019,603(5):1-9.
7. Kul'ka J., Mantič M., Kopas M., Faltinová E. Assessing the need for rope replacement in crane lifting equipment after change of crane operational parameters: Advances in science and technology Research journal. 2017,11(2):226-230.

8. Mantič M., Kul'ka J., Kopas M., Faltinová E., Hrabovský L. Limit states of steel supporting structure for bridge cranes. Scientific Journal of Silesian University of Technology. Series Transport. 2020,108:141-158.

9. Mantič M., Kul'ka J., Kopas M., Faltinová E., Petroci J. Special device for continuous deceleration of freight cableway trucks. Scientific Journal of Silesian University of Technology-Series Transport. 2016,91:89-97.

10. Michalik P., Dobranský J., Hrabovský L., Petruš M. Assessment of the manufacturing possibility of thin-walled robotic portals for conveyance workplaces. Advances in Science and Technology. Research Journal. 2018,12(1): 338-345.

11. Fries J., Hapla T., Neumann T. Optimum parameters of mining machines for specific conditions. In: International Multidisciplinary Scientific GeoConference SGEM, Sofia 2014, 435-442.

12. Brzdové obložení. Available at: www.sittech.cz/ brzdove-oblozeni (in Czech) (Access: 17.04.2020).

13. MBL 5820. Available at: www.sittech.cz/mbl-5820 (in Czech) (Access: 07.01.2021).

14. MBL 6800. Available at: www.sittech.cz/mbl-6800 (in Czech) (Access: 07.01.2021).

15. MBL 9850. Available at: www.sittech.cz/wbl-9850 (in Czech) (Access: 07.01.2021).

16. Brzdové pásy. Available at: https://gambitgl.pl/cz/ produkty/brzdove-oblozeni/brzdove-pasy.html (in Czech) (Access: 17.12.2019).

17. Brzdy. Available at: https://bmc-tech.cz/c236-brzdy (in Czech) (Access: 08.01.20209).

18. Bubnová brzda s nastavitelným brzdným momentem. Available at: www.ktr.com/cz/produkty/ elektrohydraulicke-celistove-brzdy/ktr-stop-tb-t (in Czech) (Access: 17.04.2020).

19. Kotoučová brzda s nastavitelným brzdným momentem. Available at: https:/www.ktr.com/cz/ produkty/elektrohydraulicke-celistove-brzdy/ktrstop-tb-s (in Czech) (Access: 17.04.2020).

20. Brake Lining. Available at: www.chinagrtech.com/ friction-material/brake-lining/(Access: 26.01.2021).

21. SNH 507-606 CN. Available at: https://e-shop.exvalos. cz/snh-507-606-cn/ (in Czech) (Access: 18.07.2016).

22. Single point snímače. Available at: www.hbm.cz/kategorie/snimace-a-elektronika-pro-konstrukci-vah/single-point-snimace/ (in Czech) (Access: 23.09.2011). 